\title{
Welding of dissimilar non-ferrous metals by GMAW processes
}

\author{
Belinga Mvola*, Paul Kah and Jukka Martikainen
}

\begin{abstract}
For many years, the manufacturing industry has shown interest in the opportunities offered by welding of dissimilar metals. The need for appropriate and effective techniques has increased in recent decades because of efforts to build light and strong vehicles with reduced fuel consumption. In addition, the thermal conductivity, corrosion resistance, and recyclability are other reasons to weld dissimilar non-ferrous metal. Early gas metal arc welding (GMAW) processes had limited control of the heat input, a prerequisite for effective welding of dissimilar metals, but the advanced GMAW processes of the past decades offer new perspectives. The objective of this paper is to review the main principles of the fusion welding of dissimilar metals. The study briefly investigates the challenges in welding the main possible combination of categories of non-ferrous metal. Some experiments performed on dissimilar metals using GMAW processes are then reviewed, highlighting those made using advanced GMAW processes. The study collates data from the scientific literature on fusion dissimilar metal welding (DMW), advanced GMAW processes, and experiments conducted with conventional GMAW. The study shows that the welding procedure specification is a crucial factor in DMW. Advanced GMAW processes have significant potential in the fusion welding of dissimilar non-ferrous metals of different grades. Accurate control of the heat input allows more effective prediction of the intermetallic properties and better control of post-heat treatments. Increased understanding of advanced GMAW processes will permit the development of more accurate specifications of welding procedures for DMW. Process flexibility and adaptability to robotic mass production will allow a wider range of applications and the avoidance of costly alternative methods.
\end{abstract}

Keywords: Dissimilar welding; Non-ferrous metals; Properties; Weldability; Advanced GMAW

\section{Review}

Introduction

Welding of dissimilar metals has become a critical technology in many areas, for example, $\mathrm{Mg}$ - $\mathrm{Al}$ for weight reduction in motor vehicles (Praveen and Yarlagadda 2005; Aizawa et al. 2007). Effective integration of efficient quality welding technologies for dissimilar metals will be a key component in the successful weld quality of transportation and power plant systems in the future (Hwan-Tae and Sang-Cheol 2012; Budkin 2011). The welding of dissimilar metals by melting one of the metals is efficient if the welding conditions that determine the duration of the interaction between the solid and liquid metal are strictly controlled (Budkin 2011).

\footnotetext{
* Correspondence: Eric.Mvola.Belinga@lut.fi

Department of Mechanical Engineering, Lappeenranta University of Technology, P.O. Box 20, 53851 Lappeenranta, Finland
}

The feasibility of welding processes and the properties of welded joints are influenced by many factors, for example, the alloyed element migration, the microstructure gradient, and residual stress across the different regions of the weld metal (Praveen and Yarlagadda 2005; Sun and Karppi 1996). If the welding process is not well controlled, weld defects, such as excessive dilution, cracks, and residual stresses, may develop in the weld metal, which may lead to a considerable decrease in the weld metal properties. The process of joining dissimilar metals is very sensitive because reactions between metal composition atoms can yield extremely brittle intermetallic compounds (IMCs). Friction stir welding (Aonuma and Nakata 2010), laser welding (Borrisutthekul et al. 2005), and laser-TIG (Liu et al. 2006) hybrid welding processes have been used to join dissimilar metals. Unfortunately, these methods involve expensive equipment and complex welding procedures (Zhang and Song 2011).

\section{实}

(c) 2014 Mvola et al.; licensee Springer. This is an open access article distributed under the terms of the Creative Commons Attribution License (http://creativecommons.org/licenses/by/2.0), which permits unrestricted use, distribution, and reproduction in any medium, provided the original work is properly credited. 
This paper aims to investigate and identify key improvements in the mechanical properties and microstructure compounds of dissimilar ferrous and non-ferrous metal welds. The information helps lay a baseline for advanced welding process specifications and demonstrates the potentially significant contribution that advanced gas metal arc welding (GMAW) processes can bring to this category of welding.

The study gathers key data from scientific publications related to dissimilar metal welding with both traditional GMAW processes and the latest innovations of advanced GMAW. The analysis is carried out by assessing the significant progress in joint quality made over the past decades as a result of advanced process GMAW. The paper discusses the results obtained, provides guidance on applications, and evaluates the benefits that may accrue from yet unexplored combinations. This study contributes to the development of improved welding procedure specifications for dissimilar metals welded with advanced GMAW processes.

\section{Dissimilar metal welding}

This section briefly presents important considerations when defining welding procedure specifications for the fusion welding of dissimilar metals, focusing on the GMAW process. Four critical features are to be analyzed carefully in welding specification procedure: the fundamentals of dissimilar metal welding (DMW), service considerations, and filler metal selection. Table 1 illustrates the key issues involved. The fundamental aspect is to know the weldability of the material being welded and the weld properties to match the based metal. Then, the inservice environment needs to be taken into consideration, since welding condition can affect the time-to-failure of the weld. Another consideration is the filler material; its properties and composition directly influence the weld properties. Finally, the welding process, because of its relationship with the heat input, and the type of weld pool shielding used in the dilution and the shielded component effect on the plasma and inclusion can vary significantly.

\section{Difficulties in dissimilar non-ferrous metal welding}

The dissimilar welding between non-ferrous metals can raise difficulties because it can result to very brittle intermetal compound, for example, dissolution and following diffusion of the refractory metals at the fusion area. Sometimes, in order to reduce diffusion, extension and insert are used (Fridlyander 2001; Babel et al. 2007; Menzemer et al. 2001; Lakshminarayanan et al. 2009). Table 2 presents common association of dissimilar non-ferrous joints. For six different main combinations (aluminum-titanium, titanium-nickel, titanium-copper, copper-aluminum, copper alloys to nickel, magnesium-aluminum), observations
Table 1 Considerations for welding procedures (O'Brien 2011)

\begin{tabular}{ll}
\hline Considerations & Observations \\
\hline Fundamentals & - In contrast to similar material welding, the \\
& differences between the base metal and the weld \\
& metal must be carefully analyzed. \\
& - The most important consideration is the weld metal \\
& composition and its properties. \\
Service & - The combination of metal joints depends upon the \\
consideration & mechanical and physical properties, microstructural \\
& stability, and resistance to oxidation and corrosion \\
& in-service. \\
& - The mechanical and physical properties of the weld \\
& metal as well as those of the two heat-affected \\
& zones must be suited for the intended service. \\
Filler metal & The selected filler metal must be compatible with \\
selection & the base metals to be joined so that the four major \\
& areas (metallurgical compatibility, mechanical \\
properties, physical properties, corrosion properties) & of requirements are met by the welds produced. \\
& - Filler metal selection can best be accomplished by \\
& using a combination of scientific principles and \\
manufacturing and service experience of the & industrial disciplines involved.
\end{tabular}

on and difficulties encountered in welding various dissimilar non-ferrous metals are summarized.

Aluminum and titanium fusion welds form intermetallic compounds $\left(\mathrm{TiAl}_{3}, \mathrm{Ti}_{2} \mathrm{Al}_{20}\right)$ that are exceedingly brittle, which decreases the mechanical properties of $\mathrm{Ti} / \mathrm{Al}$ joint. An improvement in welding technology and proper filler wire (Al-Cu-La wire) has resulted in tensile strength enhancement (Korenyuk 1975).

Titanium is difficult to fusion weld to a nickel base alloy because it forms brittle intermetallic compounds with almost every element contained in such alloys $(\mathrm{Ni}, \mathrm{Fe}, \mathrm{Cr}, \mathrm{Mn}$, and $\mathrm{Si}$ ). However, the use of buttering (columbium or copper alloy) and better control of welding parameters can improve mechanical properties of the joint (Gorin 1964; Lv et al. 2012).

The physical properties of titanium differ greatly from those of copper. Moreover, the solubility of copper in $\alpha$ titanium is low. The joint with pure copper and titanium alloy (Ti-30b and Ti-3Al-6.5Mo-11Cr) and titaniumand copper-based alloy $(\mathrm{Cu}-0.8 \mathrm{Cr})$ exhibited the best tensile strength and ductility (Mikhailov et al. 1965).

Aluminum to copper dissimilar welds are also limited by the formation of brittle intermetallic compounds. The weld with GMAW can be successful with a buttering of silver-based metal and a consumable aluminumbased metal (Cook and Stavish 1956). 
Table 2 Combinations of DMW of non-ferrous metals

\begin{tabular}{|c|c|c|c|}
\hline Combination & Observation & Difficulties & Reference \\
\hline $\begin{array}{l}\text { Aluminum to } \\
\text { titanium }\end{array}$ & $\begin{array}{l}\text { This combination has not been accomplished } \\
\text { successfully by conventional arc welding processes. }\end{array}$ & $\begin{array}{l}\text { These metals form intermetallic compounds during } \\
\text { fusion that are exceedingly brittle }\left(\mathrm{Ti}_{3} \mathrm{Al} \text {, TiAl, and } \mathrm{TiAl}_{3}\right) \text {. }\end{array}$ & Korenyuk (1975) \\
\hline $\begin{array}{l}\text { Titanium to } \\
\text { nickel }\end{array}$ & $\begin{array}{l}\text { An attempt to weld Ti and Ni using TIG was not } \\
\text { successful. However, the use of columbium or } \\
\text { copper alloy as an insert led to a joint without } \\
\text { harmful intermetallic compounds. }\end{array}$ & $\begin{array}{l}\text { These metals form brittle intermetallic compounds with } \\
\text { almost every element contained in the alloys ( } \mathrm{Ni}, \mathrm{Fe}, \mathrm{Cr} \text {, } \\
\mathrm{Mn} \text {, and Si). }\end{array}$ & $\begin{array}{l}\text { Gorin (1964), } \\
\text { Lv et al. (2012) }\end{array}$ \\
\hline \multirow[t]{2}{*}{$\begin{array}{l}\text { Titanium to } \\
\text { copper }\end{array}$} & \multirow{2}{*}{$\begin{array}{l}\text { The joints with the highest tensile strength and } \\
\text { ductility were those produced with Ti-30Cb and } \\
\text { Ti-3Al-6.5Mo-11Cr }\end{array}$} & $\begin{array}{l}\text { The physical properties of titanium differ greatly from } \\
\text { those of copper. }\end{array}$ & \multirow[t]{2}{*}{ Mikhailov et al. (1965) } \\
\hline & & The solubility of copper in a-titanium is low. & \\
\hline \multirow[t]{2}{*}{$\begin{array}{l}\text { Copper to } \\
\text { aluminum }\end{array}$} & $\begin{array}{l}\text { Before GMAW welding, a layer of a silver-based filler } \\
\text { metal (Ag-15.5Cu-17.5Zn-18Cd) was deposited on } \\
\text { the surfaces of the copper work piece. }\end{array}$ & \multirow[t]{2}{*}{$\begin{array}{l}\text { The use of this combination is limited by the formation } \\
\text { of brittle intermetallic compounds during the fusion } \\
\text { process. }\end{array}$} & \multirow[t]{2}{*}{$\begin{array}{l}\text { Lezovskaya and } \\
\text { Rabkin (1966), Cook } \\
\text { and Stavish (1956) }\end{array}$} \\
\hline & $\begin{array}{l}\text { The chemical compound } \mathrm{CuAl}_{2} \text { contains } 54.1 \% \\
\text { copper and will form a eutectic reaction with a } \\
\text { solid solution of copper in aluminum. }\end{array}$ & & \\
\hline \multirow{2}{*}{$\begin{array}{l}\text { Copper alloys } \\
\text { to nickel }\end{array}$} & Copper and nickel are mutually soluble in each other. & \multirow{2}{*}{$\begin{array}{l}\text { Welding these two metals and their alloys does not } \\
\text { present serious problems. }\end{array}$} & \multirow[t]{2}{*}{ O'Brien (2011) } \\
\hline & Copper-nickel or nickel-copper filler can be used. & & \\
\hline \multirow[t]{2}{*}{$\begin{array}{l}\text { Magnesium } \\
\text { to aluminum }\end{array}$} & \multirow[t]{2}{*}{$\begin{array}{l}\text { Due to the brittleness of the intermetallic compound, } \\
\text { the intermetallic formation has to be controlled and } \\
\text { kept as low as possible. }\end{array}$} & $\begin{array}{l}\text { The intermetallic compound is found in the phase } \\
\text { diagram between } \mathrm{Mg} \text { and } \mathrm{Al}: \mathrm{Al}_{2} \mathrm{Mg}_{2}, \mathrm{Al}_{12} \mathrm{Mg}_{17} \text {, and } \\
\mathrm{Al}_{30} \mathrm{Mg}_{23} \text {, even at relatively low temperatures. }\end{array}$ & \multirow[t]{2}{*}{ Murray (1982) } \\
\hline & & $\begin{array}{l}\text { There is a small difference in the melting point between } \\
\text { magnesium and aluminum. }\end{array}$ & \\
\hline
\end{tabular}

Copper and nickel are mutually soluble in each other. Therefore, welding these two metals and their alloys does not present serious problems (Lezovskaya and Rabkin 1966; Cook and Stavish 1956).

Magnesium-aluminum fusion welding results to intermetallic compounds $\left(\mathrm{Al}_{3} \mathrm{Mg}_{2}, \mathrm{Al}_{12} \mathrm{Mg}_{17}\right.$, and $\left.\mathrm{Al}_{30} \mathrm{Mg}_{23}\right)$ (Zeng et al. 2001). Due to brittleness of intermetallic compounds (IMCs), the intermetallic compound formation has to be controlled and kept at their minimum possible during welding process (O'Brien 2011).

\section{Case studies}

An abundant literature focuses on gas tungsten arc welding (GTAW), laser beam welding (LBW), and friction stir welding (FSW). Although the productivity of GTAW is less than that of GMAW, and LBW and FSW are expensive and not very versatile, the research gives an indication of the properties of the joints formed and allows for an objective analysis by making possible a comparison with available experience of advanced GMAW processes.

\section{Dissimilar welding of aluminum and magnesium}

Welding aluminum and magnesium alloys to form a component structure can reduce the weight of the structure and the cost of the component. The potential mass saving can find use in applications in the automotive and transportation industry (Zeng et al. 2001; Paramsothy et al. 2008). Although $\mathrm{Mg} / \mathrm{Al}$ dissimilar metal welding is still limited, promising results have been achieved in recent investigations. Shang et al. (2012) investigated dissimilar metal welding between AZ31B Mg (EN-MAMgAl3Zn1 according to EN 12438), $6061 \mathrm{Al}$ (EN AW-AlMg1SiCu according to EN 573-3), and pure copper consumable electrode, which were joined using the advanced GMAW process of cold metal transfer (CMT) welding. The result showed better mechanical properties than non-controlled GMAW process. Figure 1a,b shows optical micrographs of the fusion zone, the $\mathrm{Mg}$ side and $\mathrm{Al}$ side, respectively. A variety of $\mathrm{Al}-\mathrm{Cu}$ intermetallic compounds were observed: $\mathrm{AlCu}, \mathrm{CuAl}_{2}$, and $\mathrm{Cu}_{9} \mathrm{Al}_{4}$ were present in the fusion zone, and a $\mathrm{Cu}$-based solid solution was generated in the weld zone, while $\mathrm{Cu}_{2} \mathrm{Mg}$ and $\mathrm{Al}-\mathrm{Cu}-\mathrm{Mg}$ ternary eutectic structures were formed in the fusion zone of the $\mathrm{Mg}$ side, as indicated in Liu et al. (2006) and Li et al. (2007).

The distribution of the micro-hardness of one sample in the study by Shang et al. (2012) is shown in Figure 2; the values in both sides increased sharply in the fusion zone. The maximal values were $362 \mathrm{HV}$ in the $\mathrm{Mg}$ side and $260 \mathrm{HV}$ in the $\mathrm{Al}$ side. The tensile strength of the joint was $34.7 \mathrm{MPa}$. Fractures, however, occurred in the fusion zone of the $\mathrm{Mg}$ side, where the value of microhardness was highest. AZ31 magnesium and 2B50 (EN AW-AlCu4SiMg according to EN 573-3) wrought aluminum alloys were fusion-welded using the advanced GMAW cold process (CP) in experiments by Zhang and Song (2011). Joining aluminum and magnesium alloys was feasible with zinc foil as an interlayer, the presence of which prevents weld burn-through and 


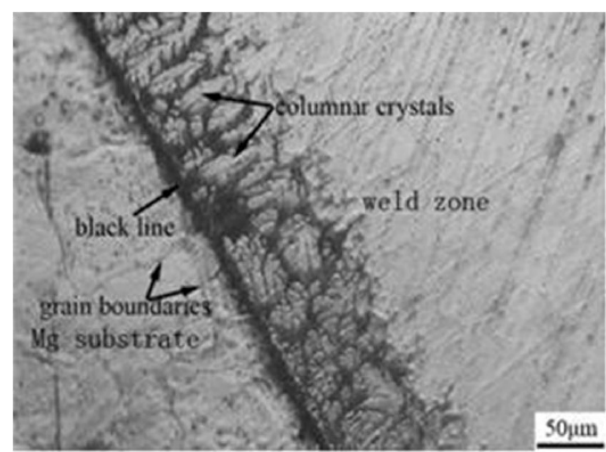

a Optical micrograph in fusion zone of $\mathrm{Mg}$

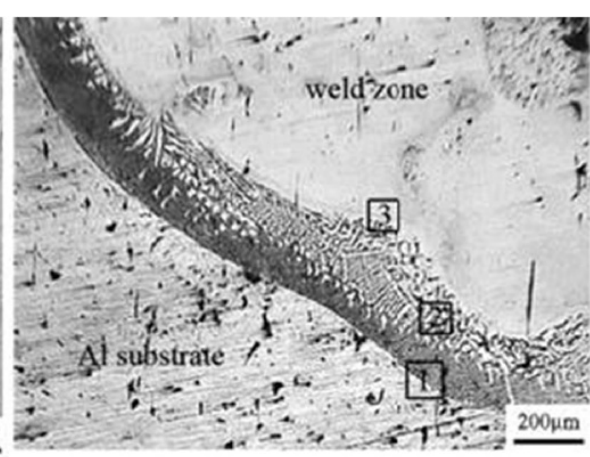

b Optical micrograph in fusion zone of Al side

Figure 1 Optical micrographs of Mg/Al dissimilar metal welds (Shang et al. 2012). Optical micrographs of the fusion zone of the (a) Mg side and (b) Al side.

macroscopic cracking. There was an absence of Al-Mg compounds when zinc foil was used as the interlayer. The tensile strength of the lap joint reached $64 \mathrm{MPa}$. These results are particularly important because they support the hypothesis that enhancing the welding process improves the mechanical properties of $\mathrm{Mg} / \mathrm{Al}$ dissimilar welds.

\section{Dissimilar welding of aluminum grades}

Welding of aluminum of different grades is of interest in several manufacturing industries. In vehicle manufacture, for example, it can constitute an alternative to dissimilar metal welding of steel to aluminum, the aim of which is to reduce the weight and fuel consumption of the structure (Hirsch 1996). In shipbuilding, the high corrosion resistance and specific properties of aluminum are considered desirable: for example, single- and multiple-hull highspeed ferries employ several aluminum alloys in sheet and plate section all welded together (Kaufman 2003).

Luijendijk (2000) conducted experiments in which different grades of aluminum were welded using GTAW with different filler metals. The ultimate tensile test strength (UTS) result, given in Figure 3, showed that the UTS of welds with dissimilar materials of strain hardened alloys of the 5xxx series (EN AC-AlMg9 according to EN 573-3) does not depend significantly on the travel speed and the plate thickness of the material. Only a small increase in strength was measured with increasing travel speed and decreasing plate thickness. Menzemer et al. (1999) carried out an experiment with AA6061 and AA5083 (EN AW-AlMg4.5Mn0.7 according to EN 573-3) with electrode 5053 to weld a dissimilar fillet

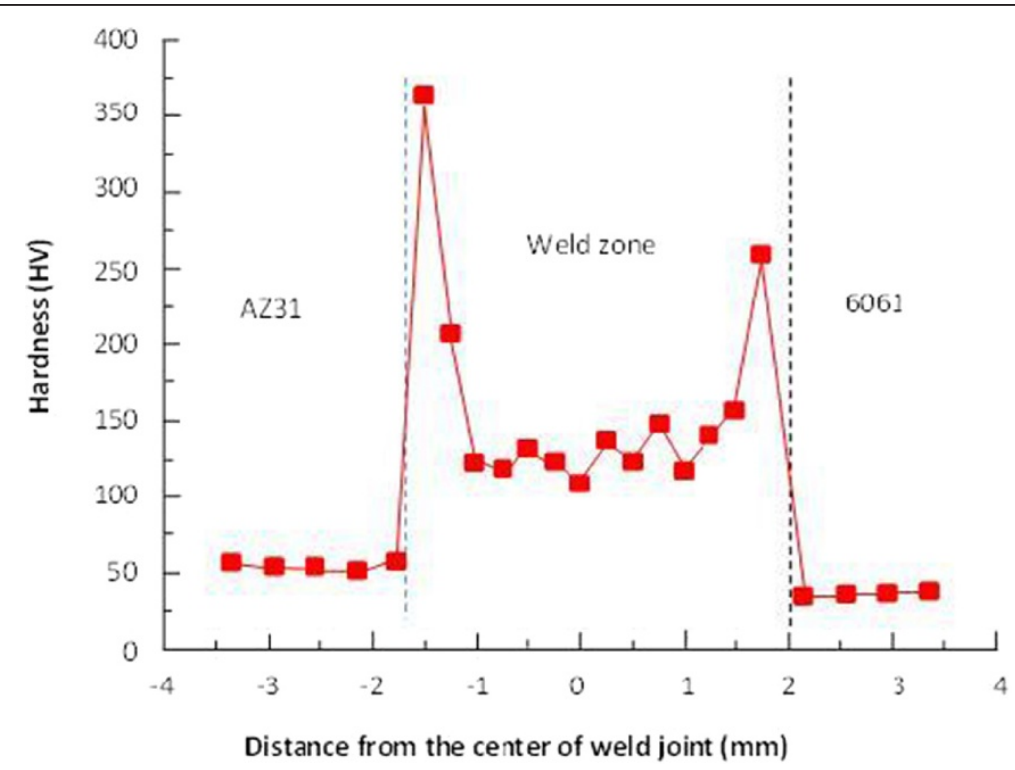

Figure 2 Micro-hardness distribution of AZ31B Mg/6061 Al in the welded joint (Shang et al. 2012). 


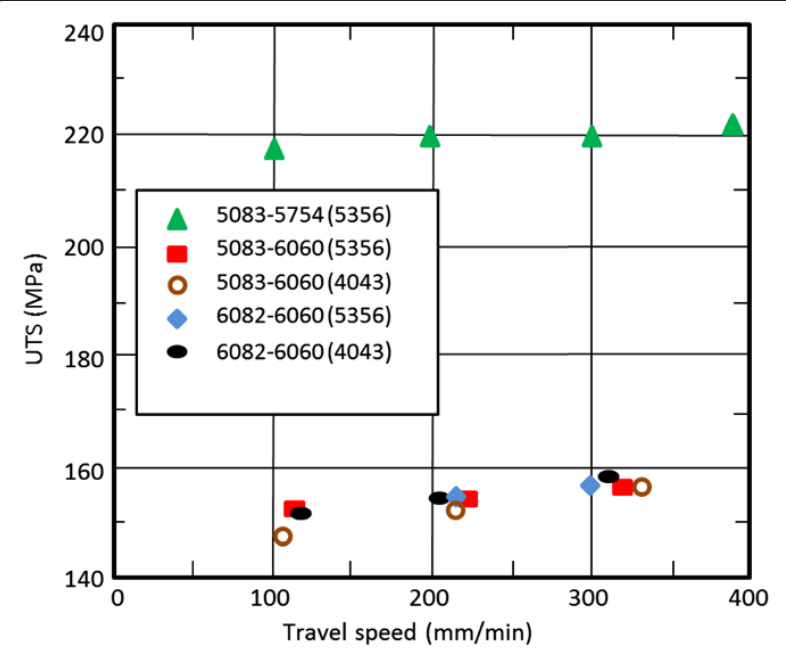

Figure 3 Ultimate tensile strength (UTS) versus travel speed for three different material combinations. Thickness $5 \mathrm{~mm}$; filler metals ER5356 and ER4043 (Luijendijk 2000).

weld by a manual GMAW process. The result revealed that the manual welding process produces adequate fusion while minimizing structural defects. Both findings suggest that dissimilar welding aluminum can be achieved successfully by fusion welding. The performance of manual GMAW can be significantly enhanced by using advanced GMAW processes.

Pulsed GMAW for welding 6061 and 7075 (EN AW$\mathrm{AlZn} 5.5 \mathrm{MgCu}$ according to EN 573-3) alloys in various combinations was investigated by Sevim et al. (2012). Their study used an advanced synergic pulsed GMAW process that applies a digital power source with software to control the welding operation. It was shown that prewelding aging heat treatment improves the mechanical properties of the weld.

The effects of the pulsed current of GTAW and postweld aging treatment on the tensile properties of argon arc-welded high-strength $7075 \mathrm{Al}$ alloy were studied in Balasubramanian et al. (2007). The enhancement in strength was approximately $25 \%$, compared with continuous current gas metal arc welding joints, and an additional enhancement in strength of $8 \%$ to $10 \%$ was obtained by the post-weld aging treatment. In addition, the pulsed current effect on $6061 \mathrm{Al}$ was investigated in Kumar et al. (2007), where it was found to improve the mechanical properties of the welds compared to continuous current welds due to grain refinement occurring in the fusion zone.

Beytullah et al. (2014) studied the characteristics of dissimilar 5083-H11 and 6082-T651 aluminum alloys. These alloys are used particularly in the shipbuilding industry due to their high corrosion resistance and moderate strength. Two base metals of 6-mm-thick plates were butt-welded using pulsed robotic CMT GMAW technology. The filler metal used was ER 183 with 1.2-mm diameter. Figure 4 shows images from light optical microscopy (LOM) for a cross section of one sample of the experiment. Although it was expected that $\mathrm{Mg}_{2} \mathrm{Al}_{3}$ would be formed, which could begin to coalesce and coarsen in the heat-affected zone (HAZ), where the temperature rises to around $250^{\circ} \mathrm{C}$ and further, there was no coalescence or coarsening in the HAZ. Nevertheless, finegrain microstructures were produced, which involved static recrystallization in the HAZ close to the fusion line (Cross et al. 2003; Mathers 2002). Although conventional GMAW showed lower mechanical test results compared to GTAW or FSW, CMT pulsed GMAW showed results close to FSW.

\section{Dissimilar welding of aluminum and copper}

Interest in welding aluminum and copper is due to the need to optimize the characteristics of high-power electronics systems. Copper provides excellent electrical conductivity, even though it is expensive. Aluminum has good electrical conductivity, is affordable, and lighter than copper. The association of both metals could result in significant cost savings. Moreover, the use in motor vehicles of auxiliary motors and other electronic devices is increasing with the growing popularity of hybrid systems; the cables and cable systems in such arrangements weigh about 15 to $45 \mathrm{~kg}$ (Wetzel 2012). Thus far, very little attention has been paid to GMAW processes in the welding of aluminum and copper, although new advanced GMAW technology potentially offers significant gains.

Mozhaiskaya and Chekanova (1990) investigated the structure and properties of welded aluminum-copper joints. It is of practical interest to obtain an efficient $\mathrm{Al}-\mathrm{Cu}$ fusion butt joint, for example, in pipelines in a refrigeration unit. Figure 5 presents the transition zone of the joint studied by Park et al. (2009). Its width is 20 to $25 \mu \mathrm{m}$ (average micro-hardness value $82 \mathrm{H}$ ). X-ray microanalysis indicated the presence in this zone of a hypereutectic alloy (in atomic fractions) of $9.3 \% \mathrm{Cu}$ and $89.8 \% \mathrm{Al}$. Based on the results from the study by Park et al. (2009) on the effect of the control of heat input by advanced welding process on the size of IMCs, it may be possible to significantly reduce the thickness of the IMC of the $\mathrm{Cu}$-Al welded joint. In addition, the use of buttering or an AlSi12 filler between the $\mathrm{Cu}$ and $\mathrm{Al}$ could also contribute to increased dissimilar weld ductility (Weigl et al. 2011). However, it should be noted that there is still need for investigations to accurately determine a proper and suitable consumable electrode.

\section{Dissimilar welding of copper and magnesium}

Dissimilar joining of magnesium alloys to copper is of great industrial significance for it allows design engineers to utilize the excellent properties of both materials. An 


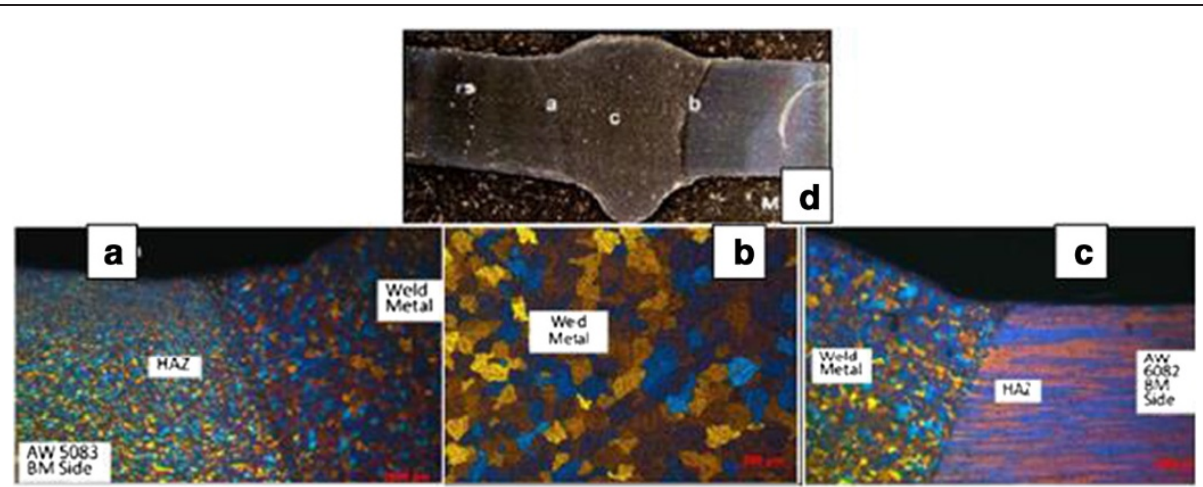

Figure 4 Microstructure of dissimilar Al grades $\mathbf{5 0 8 3}$ and 6082. (a) Higher magnification zone a, (b) higher magnification zone c, (c) higher magnification zone b, and (d) microscopic section (Beytullah et al. 2014).

effective joint of copper and magnesium not only meets the requirements of heat conduction, electrical conduction, wear resistance, and corrosion resistance but also satisfies the demand for light weight and high strength. Therefore, this joint may have broad application prospects, among others, in the aerospace, shipbuilding, and instrument fields.

Liu et al. (2008) studied a dissimilar GTAW lap joint of magnesium and copper. Two cases were studied: a direct welded joint (Figure 6a,b) and the use of an iron interface (Figure 6c,d,e). It was found that the use of an Fe interface layer provided better mechanical properties for the dissimilar joint. In Figure $6 \mathrm{~b}$, a diffusion layer about $150 \mu \mathrm{m}$ thick can be observed in the interfacial region between the copper and the magnesium alloy. Figure $6 \mathrm{~d}$ shows a micrograph of the interface between the iron and copper. $\mathrm{Cu}$ atoms and $\mathrm{Fe}$ atoms diffuse into each other to form a solid solution. From Figure 6e, it can be seen that although Fe cannot dissolve in $\mathrm{Mg}$, even in liquid form, a short diffusion happened between the Fe element and $\mathrm{Mg}$ element because of the action of oxygen (Pierre et al. 2003). The main cause of the weakness of $\mathrm{Cu} / \mathrm{Mg}$ welds is the $\mathrm{IMC}\left(\mathrm{MgCu}_{2}\right.$ and $\mathrm{Mg}_{2} \mathrm{Cu}$ ). However, better control of the welding parameters can contribute to reducing the IMC zone and improving the strength of the joint. The benefits of dissolution control can be gained by using an $\mathrm{Fe}$ interface.

\section{Dissimilar welding of titanium and copper}

Dissimilar welds between titanium and copper may have broad application in the aerospace, shipbuilding, and instrument fields. However, the mutual solubility of titanium and copper is limited. Moreover, because of the large differences between the thermophysical properties of the two materials and the formation of brittle $\mathrm{Ti}-\mathrm{Cu}$ IMCs at elevated temperatures, the joining of titanium to copper is a great challenge.

Joining a titanium alloy to a copper alloy has been investigated for various processes, for instance, mechanical, solid state, fusion, and brazing joining. For example, Shiue et al. (2004a, b) reported the microstructure and properties of joints between commercial pure titanium plate and oxygen-free copper plate by infrared brazing.

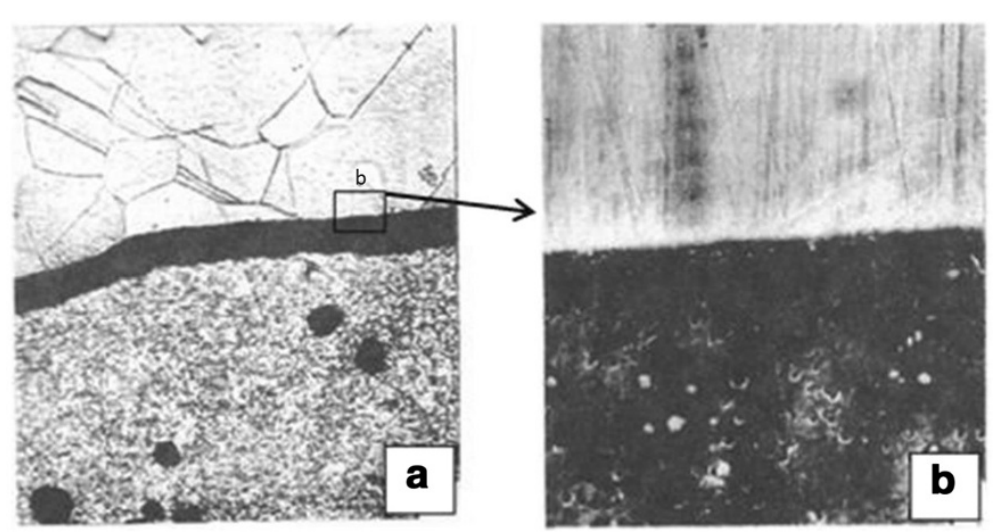

Figure 5 Microstructure of Cu and Al fusion dissimilar weld. (a) fusion butt welding; (b) higher magnification zone b (Park et al. 2009). 

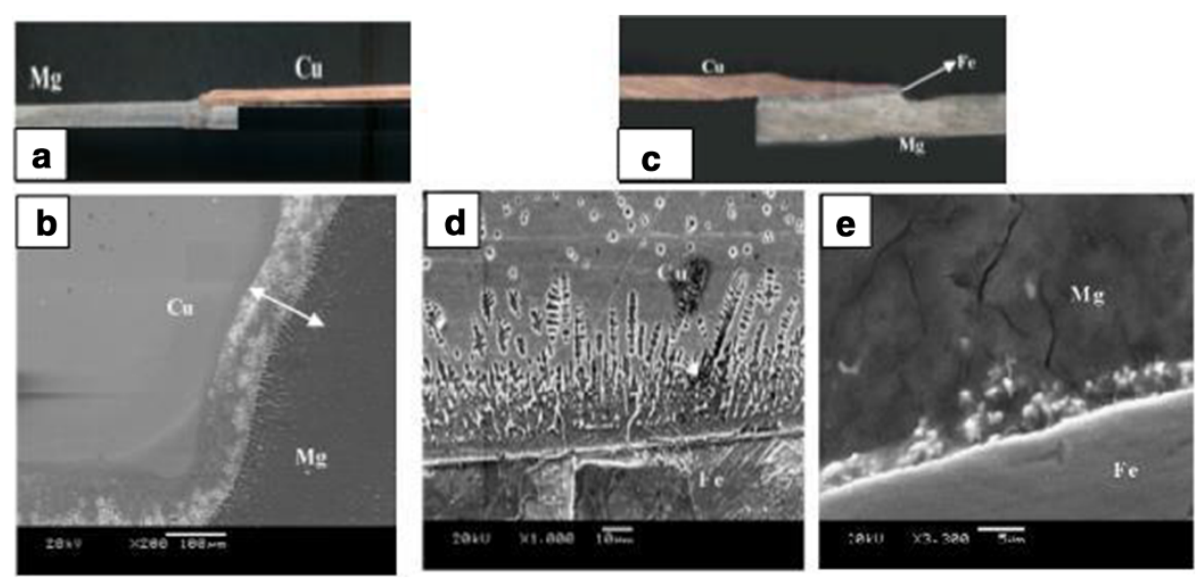

Figure 6 Micrographic dissimilar Cu/Mg lap joint. (a) direct Cu/Mg, (b) fusion zone Cu/Mg, (c) Cu/Mg with interface Fe, (d) Cu/Fe side, and (e) Mg/Fe side (Liu et al. 2008).

The joint was primarily composed of $\mathrm{Cu}_{4} \mathrm{Ti}$ and $\mathrm{Cu}_{2} \mathrm{Ti}$ phases, and three interface reaction layers, $\mathrm{CuTi}_{2}, \mathrm{CuTi}$, and $\mathrm{Cu}_{4} \mathrm{Ti}_{3}$, were observed after infrared brazing.

Despite the ability of advanced adaptive GMAW processes to achieve accurate control of the heat input, their use in titanium to copper welding has not been studied intensively. However, Cao et al. (2014) investigated the microstructure and properties of titanium-copper dissimilar joints welded by cold metal transfer technology and advanced GMAW process. Performing a lap joint on a commercial pure titanium TA2 to pure copper T2 with ERCuNiAl copper wire revealed that a satisfactory lapped joint could be achieved by the CMT welding method. Figure 7 shows a dissimilar lap joint from the study by Cao et al. (2014) presenting the microstructure of the fusion zone between $\mathrm{Cu}$ and $\mathrm{Ti}$. Despite the presence of IMCs, such as $\mathrm{Ti}_{2} \mathrm{Cu}$ and $\mathrm{TiCu}$, and an $\mathrm{AlCu}$ layer between the weld and the titanium part, the tensile shear strength achieved varied from 192.5 to $197.5 \mathrm{~N} / \mathrm{mm}$ for the sample tested. The IMC layers at titanium-weld interface were 140 to $160 \mu \mathrm{m}$. However, another study from Aydin et al. (2012) on diffusion welding of titanium/ copper dissimilar weld indicated that the thickness of IMCs was about 125 to $250 \mu \mathrm{m}$. It can be deduced that

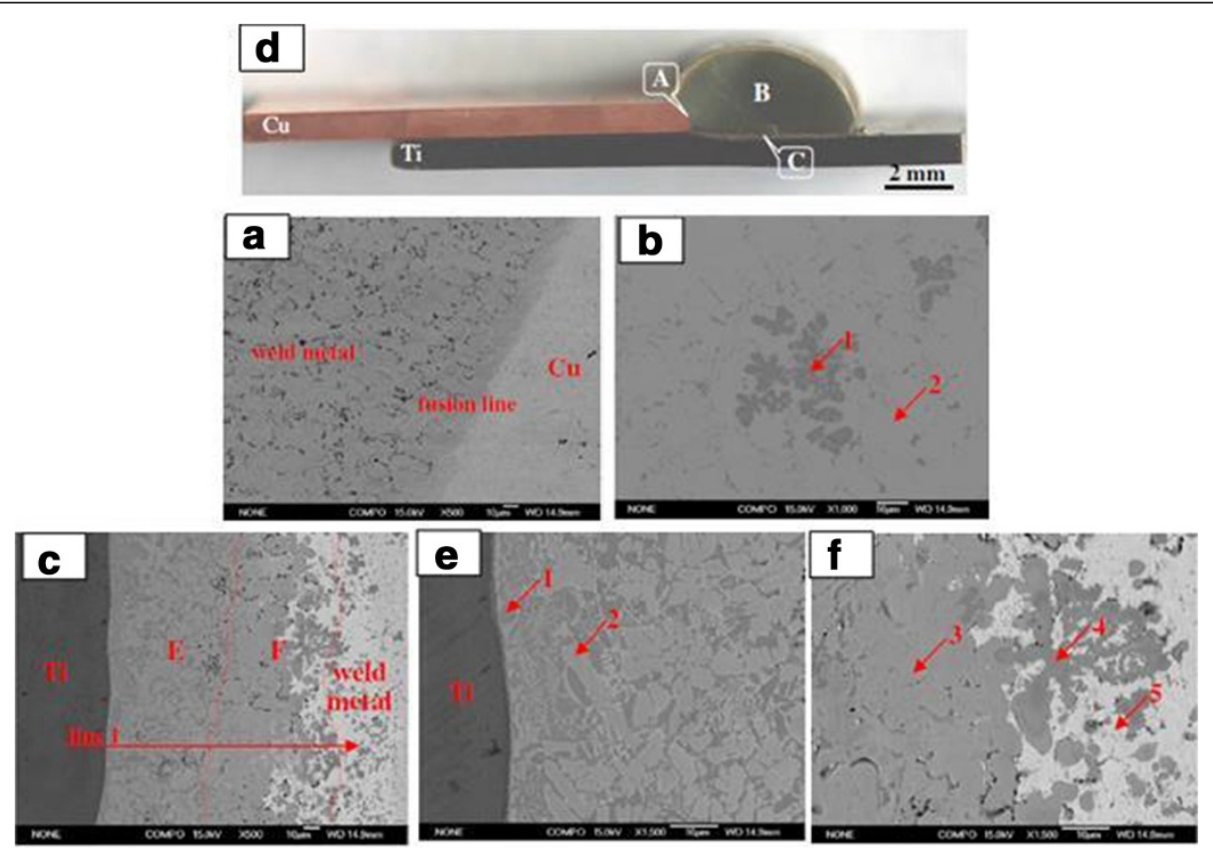

Figure 7 Microscopic section Cu/Ti and microstructure. (a) Zone A, (b) zone B, (c) zone C, (d) lap joint of dissimilar Cu/Ti, (e) higher magnification of zone $\mathrm{E}$, and (f) higher magnification of zone $\mathrm{F}$ (Cao et al. 2014). 
the tensile properties increased because of control over the heat input, which reduced the thickness of the intermetallic compound.

\section{Dissimilar welding of titanium and nickel}

Due to the excellent characteristics of good corrosion resistance, high strength, and creep resistance, titanium alloys have been widely used in the industry. One of the biggest application areas is in the aerospace industries, for instance, as static and rotating components in turbine engines. Nickel alloys of high-temperature ability are also widely used in the aerospace industries. Their superior mechanical properties and oxidation resistance at elevated temperatures make nickel alloys suitable for high-temperature aero engines and gas turbines.

A lot of research has been conducted into welding both materials by laser-based processes (Chatterjee et al. 2006; Chen et al. 2010); however, no systematic studies have so far been done concerning the use of advanced adaptive GMAW, although unsuccessful joints were reported by conventional GTAW (Gorin 1964). The progress achieved with the application of laser welding and other studies focusing on the microstructure of $\mathrm{Ti} / \mathrm{Ni}$ DMW provide pertinent information for forecasting possible results if heat input is carefully controlled.

The study by Seretsky and Ryba (1976) tried to characterize the metallurgy of dissimilar welds produced with laser welding. In their work, they wanted to promote the TiNi phase in the weld, which is of particular interest because of its ductility, non-magnetic nature, corrosion resistance, and good low-temperature toughness. In addition, the TiNi phase exhibits a shape memory effect. The results of their laser welding experiments were unsuccessful because of poor microstructures. The cracking could not be eliminated by changing the laser power. The microstructure development of the dissimilar $\mathrm{Ti}$ and $\mathrm{Ni}$ intermetallic phase has also been studied by Chatterjee et al. (2006), who present and discuss the development of the solidification microstructure in a laser-welded $\mathrm{Ti} / \mathrm{Ni}$ dissimilar binary couple. Figure $8 \mathrm{a}$ shows the fusion interface at the Ni side. It can be seen that there are three bands running parallel to the interface. Figure $8 \mathrm{~b}$ is a higher magnification of band $\mathrm{A}$, which reveals two distinct sub-layers ( $\mathrm{Ni}$ and $\mathrm{Ni}_{3} \mathrm{Ti}$ ). Figure $8 \mathrm{c}$ is a higher magnification of bands $\mathrm{C}$ and $\mathrm{B}$, with a eutectic $\left(\mathrm{Ni}_{3} \mathrm{Ti}+\mathrm{NiTi}\right)$ in band $\mathrm{B}$ when a monolithic NiTi layer forms in band C. A more recent study by Chen et al. (2010) successfully joined Ti-6Al-4V and Inconel 718 (Special Metals Corp., New Hartford, NY, USA) using fiber laser welding. It was suggested that the laser beam be offset approximately $35 \mu \mathrm{m}$ from the interface to the Inconel 718 using a combination of a higher laser power and higher welding speed. As a consequence of these settings, lower formation of $\mathrm{Ti} / \mathrm{Ni}$ intermetallic brittle phases was observed. Based on these findings, it can be conjectured that advanced GMAW could be used to attain lower intermetallic thickness and suitable filler metal could be used to improve welded $\mathrm{Ti} / \mathrm{Ni}$ properties.

\section{Comparison and benefit}

This section compares advanced GMAW concepts with conventional GMAW process in welding of dissimilar metals. Table 3 presents the relationship between welding control technologies, combinations of base metals, and expected weld quality. It can be clearly seen that the control mode has a very significant effect on the chemical, physical, and mechanical properties of the weld. The control mode regulates the size of the heat-affected zone, the composition of intermetallic compounds, the microstructure of the weld and the heat-affected zone, and thus, the overall weld quality. The attainment of acceptable weld properties requires a thin layer of intermetallic compound, sufficient dilution to minimize migration of alloy elements, and avoidance of an excessive heat-affected zone, which would result in softening of the area.

\section{Conclusions}

This study investigated advanced and adaptive GMAW processes as applied to dissimilar welding and discussed fusion welding of dissimilar non-ferrous metal to improve welding procedure specifications. Based on the review of previous studies, the following conclusions can be drawn:

The welding quality of dissimilar non-ferrous metals is enhanced by using an appropriate process. $\mathrm{Mg} / \mathrm{Al}$ dissimilar metals could be successfully joined by CMT welding, with pure copper as a filler metal. A variety of $\mathrm{Al}-\mathrm{Cu}$ intermetallic compounds were formed, and the bonding strength of the joint was $34.7 \mathrm{MPa}$. Fractures occurred in the fusion zone of the $\mathrm{Mg}$ side, where the value of micro-hardness was highest. The fractures occurred in locations with embrittlement compounds. AZ31 magnesium and 2B50 wrought aluminum alloys were successfully fusion-welded using an advanced GMAW CP.

The melting zone and HAZ of the GMAW welds had different widths with heat-treated 6061 and 7075 alloys in various combinations. The hardness value of the welded metals can increase significantly depending on the aging temperature and time. The tensile strength and hardness values of the weld increase with the intermetallic formation accomplished. Joining aluminum and magnesium alloys is feasible with zinc foil as the interlayer, the presence of which prevents weld burn-through and macroscopic cracking.

Welding of $\mathrm{Al}-\mathrm{Cu}$ dissimilar joints using GMAW processes has not been studied intensively, although potential cost savings in car construction are significant. 


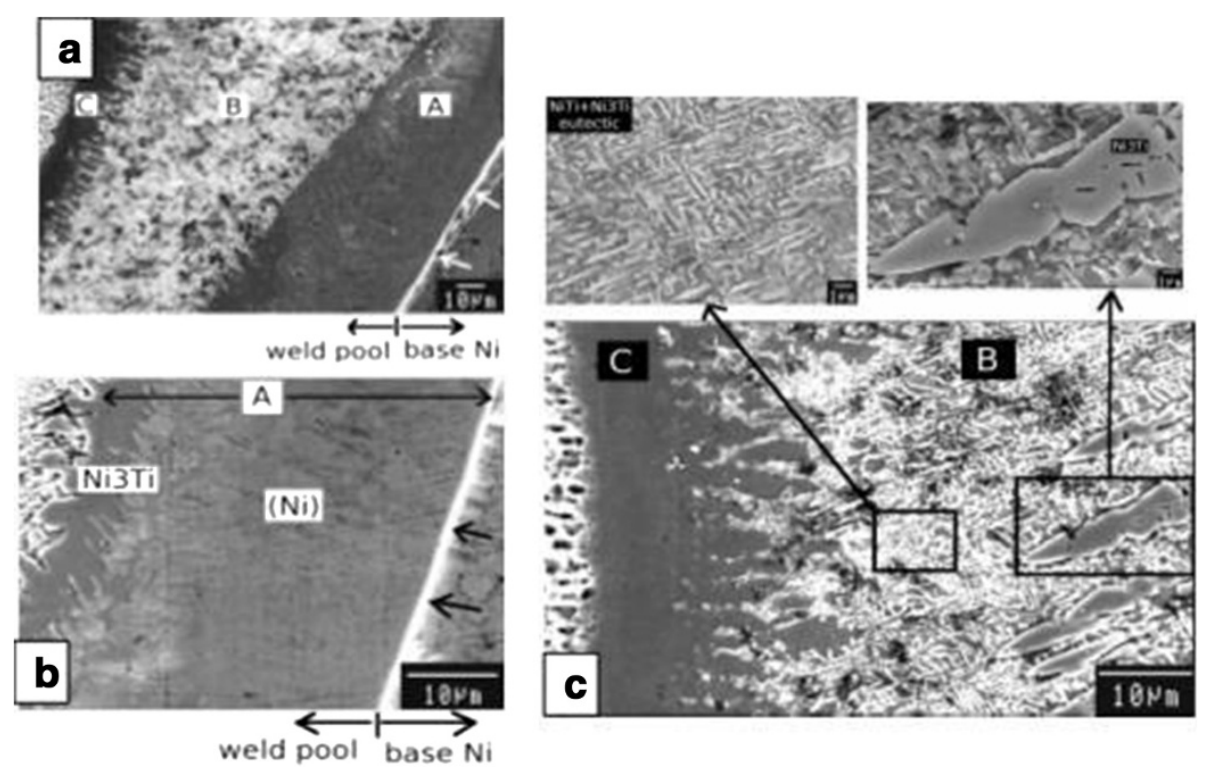

Figure 8 Weld microstructure near the fusion line. (a) Fusion line at the Ni fusion interface with A, B, and C bands, (b) higher magnification of $A$ area, and (c) higher magnification of $C$ and B (Chatterjee et al. 2006).

The occurrence of the intermetallic phase cannot be avoided; however, the use of advanced technology can reduce the interface layer thickness. A matching electrode or an interface matching material could be used to mitigate the intermetallic phase. The expected result would increase the tensile strength of the joint.

Welding of $\mathrm{Cu}-\mathrm{Mg}$ joints can be successfully achieved directly between both metals; however, the joint is weakened as a result of intermetallic phases - the larger the intermetallic compound layer, the weaker the joint. The properties of the welded metals can improve significantly if the IMC layers are kept at the minimum. An alternative to weld directly $\mathrm{Cu}$ to $\mathrm{Mg}$ will be to use an iron interface between both metals, which increases the strength of the weld joint.
$\mathrm{Ti}$ and $\mathrm{Cu}$ can be welded successfully by advanced welding GMAW technology. When applied on a lap joint, the process results in acceptable joint properties in terms of the mechanical properties and low diffusion of the intermetallic compound. The position of the base metal affected the weld appearance. The weld with $\mathrm{Cu}$ on top provided a better bead appearance, whereas when it was put on the bottom, the dilution crossed the thin plate section.

$\mathrm{Ti}$ and $\mathrm{Ni}$ have been successfully welded by the laser process. Available experience does not give enough information directly related to the GMAW process that is applicable to both metals. Studies have given some indication about the evolution of the microstructure of Ti-Ni dissimilar metal welds, and it has been shown that

Table 3 Comparison of advanced GMAW concepts when used in DMW

\begin{tabular}{|c|c|c|c|c|}
\hline Control Technique & & Limitation & Effect on the joint & $\begin{array}{l}\text { Observations of } \\
\text { applicability }\end{array}$ \\
\hline \multirow[t]{2}{*}{$\begin{array}{l}\text { Advanced and adaptive } \\
\text { GMAW }\end{array}$} & $\begin{array}{l}\text { Wave form } \\
\text { control }\end{array}$ & $\begin{array}{l}\text { If restricted to the wave form, the technique } \\
\text { may only affect control of heat input and } \\
\text { stability of the arc. }\end{array}$ & $\begin{array}{l}\text {-Thickness control of IMCs } \\
\text {-Dilution controlled } \\
\text {-Better heat treatment }\end{array}$ & Very good capability \\
\hline & $\begin{array}{l}\text { Wave form and } \\
\text { filler control }\end{array}$ & $\begin{array}{l}\text { If restricted to the wave form and alternative } \\
\text { wire motion, the technique may only affect } \\
\text { control of heat input and stability of the arc. }\end{array}$ & $\begin{array}{l}\text {-Thickness control of IMCs } \\
\text {-Dilution controlled } \\
\text {-Better heat treatment } \\
\text {-Lower HAZ }\end{array}$ & $\begin{array}{l}\text { High, excellent } \\
\text { capability }\end{array}$ \\
\hline Conventional control & & $\begin{array}{l}\text { Limitations in control dramatically affect control } \\
\text { of heat input, stability of the arc, and regulation } \\
\text { of the flow gas. }\end{array}$ & $\begin{array}{l}\text {-Highest thickness IMCs } \\
\text {-Highest dilution } \\
\text {-Difficult to manage heat } \\
\text { treatment }\end{array}$ & Low capability \\
\hline
\end{tabular}


the NiTi solid stage phase has excellent ductility. However, prediction of the occurrence of IMCs during welding is not straightforward. The success of the Ti-Ni joint relies on restriction of intermetallic diffusion. Thus, by using the ability of advanced GMAW to control the heat input, it can be expected that the IMC interface layer could be kept at a minimum.

Fusion welding of dissimilar non-ferrous metals is very difficult for most combinations because there are only few solid-state compounds in the binary diagram phases. The conventional GMAW process produces variable non-ferrous welds because of poor quality control of heat input and arc stability. Inadequate control does not allow the process to meet the narrow range of solubility between non-ferrous metals (e.g., $\mathrm{Al} / \mathrm{Ti}, \mathrm{Ti} / \mathrm{Ni}$, and $\mathrm{Al} /$ $\mathrm{Mg}$ ). Enhanced control found with advanced GMAW gives the possibility to define and meet the welding parameters required. Best results are achieved by significantly reducing the intermetallic compound layers.

Selection of the welding process is a key factor when welding dissimilar non-ferrous because the heat input affects dilution and alloy element migration. The greater flexibility and sensitivity of adaptive GMAW allow a reduction in the dilution and residual stress caused by differences in the thermal coefficients.

\section{Competing interests}

The authors declared that they have no competing interests.

\section{Authors' contributions}

All authors read, analyzed, approved and wrote the final manuscript.

Received: 2 September 2014 Accepted: 26 September 2014

Published online: 17 October 2014

\section{References}

Aizawa, T, Kashani, M, \& Okagawa, K. (2007). Application of magnetic pulse welding for aluminum alloy and SPCC steel sheet joints. Welding Journal, $86,119-124$

Aonuma, M, \& Nakata, K. (2010). Effect of calcium on intermetallic compound layer at interface of calcium added magnesium-aluminum alloy and titanium joint by friction stir welding. Materials Science and Engineering B, 173(1), 135-138.

Aydin, K, Kaya, Y, \& Kahraman, N. (2012). Experimental study of diffusion welding/ bonding of titanium to copper. Mater Design, 37, 356-368.

Babel, H, Gibson, J, Tarkanian, M, Parrish, C, Prietto, M, Ordonez-Chu, A, Haberl, H, Kabisch, J, Clark, R, Ogren, J, \& Es Said, OS. (2007). 2099 aluminum-lithium with key-locked inserts for aerospace applications. Journal of Materials Engineering and Performance, 16(5), 584-591.

Balasubramanian, V, Ravisankar, V, \& Reddy, GM. (2007). Effect of pulsed current and post weld aging treatment on tensile properties of argon arc welded high strength aluminium alloy. Materials Science and Engineering A, 459, 19-34.

Beytullah, G, Erdinc, K, Emel, T, \& Aydin, S. (2014). Mechanical and microstructural properties of robotic cold metal transfer (CMT) welded 5083-H111 and 6082-T651 aluminum alloys. Materials and Design, 54, 207-211.

Borrisutthekul, R, Miyashita, Y, \& Mutoh, Y. (2005). Dissimilar material laser welding between magnesium alloy AZ31B and aluminum alloy A5052-O. Science and Technology of Advanced Materials, 6(2), 199-204.

Budkin, YV. (2011). Welding joints in dissimilar metals. Welding International, 25(7), 523-525.
Cao, R, Feng, Z, \& Chen, JH. (2014). Microstructures and properties of titanium-copper lap welded joints by cold metal transfer technology. Materials and Design, 53, 192-201.

Chatterjee, S, Abinandanan, TA, \& Chattopadhyay, K. (2006). Microstructure development during dissimilar welding: case of laser welding of Ti with $\mathrm{Ni}$ involving intermetallic phase formation. Journal of Materials Science, 41(3), 643-652.

Chen, HC, Pinkerton, AJ, \& Li, L. (2010). Fibre laser welding of dissimilar alloys of Ti-6Al-4V and Inconel 718 for aerospace applications. International Journal of Advanced Manufacturing Technology, 52(9-12), 977-987.

Cook, LA, \& Stavish, MF. (1956). Welding aluminium to copper using the inert gas metal arc process. Welding Journal, 35(5), 348-355.

Cross, EC, Olson, DL, \& Liu, S. (2003). Aluminium welding. In GE Totten, S Mackenzie, \& D Marcel (Eds.), Handbook of aluminum, vol 1: physical metallurgy and processes (pp. 481-532). New York: CRC Press.

Fridlyander, IN. (2001). Current-technology aluminum alloys for aerospace applications. Metal Science and Heat Treatment, 43(7), 297.

Gorin, LG. (1964). Welding titanium alloys to nickel-base alloys. Welding Products, $11(12), 46-53$

Hirsch, J. (1996). Aluminium alloys for automotive application. Materials Science Forum, 242, 33-50.

Hwan-Tae, K, \& Sang-Cheol, K. (2012). Research trend of dissimilar metal welding technology. MAS/ASNT 2012. CCIS, 341, 199-204.

Kaufman, JG. (2003). Introduction to aluminum alloys and tempers. Ohio: ASM International.

Korenyuk, YM. (1975). Interaction of liquid aluminium and solid titanium in fusion welding [J]. Welding Production, 22(6), 3-5.

Kumar, TS, Balasubramanian, V, \& Sanavullah, MY. (2007). Influences of pulsed current tungsten inert gas welding parameters on the tensile properties of AA 6061 aluminium alloy. Materials and Design, 28, 2080-2092.

Lakshminarayanan, AK, Balasubramanian, V, \& Elangovan, K. (2009). Effect of welding processes on tensile properties of AA6061 aluminium alloy joints. International Journal of Advanced Manufacturing Technology, 40, 286-296.

Lezovskaya, AV, \& Rabkin, DM. (1966). Fusion welding aluminum to copper. Automatic Welding, 19(7), 65-66.

Li, H, Qian, M, \& Li, D. (2007). The effect of intermetallic compounds on laser weldability of dissimilar metal joint between magnesium alloy AZ31B and aluminium alloy 6061. Laser Journal, 28(5), 61-63.

Liu, L, Liu, X, \& Liu, S. (2006). Microstructure of laser-TIG hybrid welds of dissimilar Mg alloy and Al alloy with Ce as interlayer. Scripta Materialia, 55(4), 383-386

Liu, L, Wang, S, \& Zhao, L. (2008). Study on the dissimilar magnesium alloy and copper lap joint by TIG welding. Materials Science and Engineering: A, 476, 206-209.

Luijendijk, T. (2000). Welding of dissimilar aluminium alloys. Journal of Materials Processing Technology, 103, 29-35.

LV, SX, Jing, XJ, Huang, YX, Xu, YQ, Zheng, CQ, \& Yang, SQ. (2012). Investigation on TIG arc welding-brazing of Ti/Al dissimilar alloys with Al based fillers. Science and Technology of Welding and Joining, 17(7), 519-524.

Mathers, G. (2002). The welding of aluminium and its alloys. Cambridge: Woodhead Publishing Limited.

Menzemer, C, Lam, SST, \& Wittel, FC. (1999). An investigation of fusion zone microstructures of welded aluminum alloy joints. Materials Letters, 41, 192-197.

Menzemer, CC, Lam, P, Srivatsan, TS, \& Wittel, C. (2001). A study of fusion zone microstructures of arc welded joints made from dissimilar aluminum alloys. Journal of Materials Engineering and Performance, 10(2), 173-177.

Mikhailov, AS, Slonimaky, EV, Senic, AM, \& Sukhorukov, AP. (1965). Welding titanium to copper and its alloys. Weld Product, 12(8), 1-6.

Mozhaiskaya, TM, \& Chekanova, NT. (1990). Structure and properties of welded aluminium-copper joints. Metal Science and Heat Treatment, 32(12), 938-939.

Murray, JL. (1982). The magnesium-aluminum phase diagram. Bulletin Alloy Diagrams, 3, 60-74.

O'Brien, A. (2011). Welding handbook, volume 4 - material and application. Part 1 , 9th edn. Doral: American Welding Society (AWS).

Paramsothy, M, Hassan, SF, Srikanth, N, \& Gupta, M. (2008). Toughening mechanisms in Mg/Al macrocomposites: texture and interfacial mechanical interlocking. Journal of Physics D, 41, 175402-175410.

Park, HJ, Rhee, S, Kang, MJ, \& Kim, DC. (2009). Joining of steel to aluminum alloy by AC pulse MIG welding. Materials Transactions, 50(9), 2314-2317. 
Pierre, D, Viala, JC, Peronnet, M, Bosselet, F, \& Bouix, J. (2003). Interface reactions between mild steel and liquid Mg-Mn alloys. Materials Science and Engineering: A, 349(1), 256-264

Praveen, P, \& Yarlagadda, P. (2005). Meeting challenges in welding of aluminium alloys through pulse gas metal arc welding. Journal of Materials Processing Technology, 164, 1106-1112.

Seretsky, J, \& Ryba, ER. (1976). Laser welding of dissimilar metals: titanium to nickel. Welding Journal, 55(7), 208-2012.

Sevim, I, Hayat, F, Kaya, Y, Kahraman, N, \& Şahin, S. (2012). The study of MIG weldability of heat-treated aluminum alloys. International Journal of Advanced Manufacturing Technology, 66, 1825-1834. doi:10.1007/s00170-012-4462-z.

Shang, J, Wang, K, Zhou, Q, Zhang, D, Huang, J, \& Li, G. (2012). Microstructure characteristics and mechanical properties of cold metal transfer. Materials and Design, 34, 559-565.

Shiue, RK, Wu, SK, \& Chan, CH. (2004a). The interfacial reactions of infrared brazing $\mathrm{Cu}$ and Ti with two silver-based braze alloys. Journal of Alloys and Compounds, 372, 148-157.

Shiue, RK, Wu, SK, \& Chan, CH. (2004b). Infrared brazing Cu and Ti using a 95Ag-5Al braze alloy. Metallurgical and Materials Transactions A, 35A, 3177-3186.

Sun, Z, \& Karppi, R. (1996). The application of electron beam welding for the joining of dissimilar metals: an overview. Journal of Materials Processing Technology, 59(3), 257.

Weigl, M, Albert, F, \& Schmidt, M. (2011). Enhancing the ductility of laser-welded copper-aluminum connections by using adapted filler materials. Physics Procedia, 12-B, 332-338.

Wetzel, HJ. (2012). Die Automobil eletronik der Zukunft-kabellose Infrastrukturen als Herausforderung oderBedrohung? Frankfurt: In Proceeding of the CTI Forum Automotive Wire.

Zeng, RC, Ke, W, \& Xu, YB. (2001). Recent development and application of magnesium alloys. Acta Metallurgica Sinica, 37(7), 673-685.

Zhang, H, \& Song, J. (2011). Microstructural evolution of aluminum/magnesium lap joints welded using MIG process with zinc foil as an interlayer. Materials Letters, 65, 3292-3294.

doi:10.1186/s40712-014-0021-8

Cite this article as: Mvola et al:: Welding of dissimilar non-ferrous metals by GMAW processes. International Journal of Mechanical and Materials Engineering 2014 9:21.

\section{Submit your manuscript to a SpringerOpen ${ }^{\circ}$ journal and benefit from:}

- Convenient online submission

- Rigorous peer review

- Immediate publication on acceptance

- Open access: articles freely available online

- High visibility within the field

- Retaining the copyright to your article

Submit your next manuscript at $>$ springeropen.com 